\title{
Recent progress of porcine milk components and mammary gland function
}

\author{
Shihai Zhang ${ }^{1,2}$, Fang Chen', Yinzhi Zhang ${ }^{1}$, Yantao Lv ${ }^{1,3}$, Jinghui Heng ${ }^{1}$, Tian Min ${ }^{1}$, Lilang Li' and Wutai Guan ${ }^{1,2^{*}}$ (D)
}

\begin{abstract}
As the only nutritional source for newborn piglets, porcine colostrum and milk contain critical nutritional and immunological components including carbohydrates, lipids, and proteins (immunoglobulins). However, porcine milk composition is more complex than these three components. Recently, scientists identified additional and novel components of sow colostrum and milk, including exosomes, oligosaccharides, and bacteria, which possibly act as biological signals and modulate the intestinal environment and immune status in piglets and later in life. Evaluation of these nutritional and non-nutritional components in porcine milk will help better understand the nutritional and biological function of porcine colostrum and milk. Furthermore, some important functions of the porcine mammary gland have been reported in recent published literature. These preliminary studies hypothesized how glucose, amino acids, and fatty acids are transported from maternal blood to the porcine mammary gland for milk synthesis. Therefore, we summarized recent reports on sow milk composition and porcine mammary gland function in this review, with particular emphasis on macronutrient transfer and synthesis mechanisms, which might offer a possible approach for regulation of milk synthesis in the future.
\end{abstract}

Keywords: Bioactive components, Fat, Lactose, Mammary gland, Porcine milk, Protein

\section{Background}

Piglets are born with low body fat reserves and immature immune systems. Timely colostrum intake is crucial for piglets to gain sufficient nutrients and passive immunoglobulins from the sow after piglets are exposed to environmental cold and pathogens [1]. Mei et al. [2] reported that $200 \mathrm{~g}$ of colostrum per piglet during the first $24 \mathrm{~h}$ after birth could reduce the risk of mortality before weaning. Furthermore, porcine milk has been shown to play an essential role in enhancing piglet performance [3] and stimulate visceral organ and skeletal muscle protein synthesis in neonatal piglets [4].

Traditionally, porcine milk has been considered to be mainly composed of carbohydrates, lipids, and proteins

\footnotetext{
* Correspondence: wutaiguan1963@163.com

'Guangdong Province Key Laboratory of Animal Nutrition Control, College of Animal Science, South China Agricultural University, Guangzhou 510642, China

${ }^{2}$ College of Animal Science and National Engineering Research Center for Breeding Swine Industry, South China Agricultural University, Guangzhou 510642, China

Full list of author information is available at the end of the article
}

(immunoglobulins) with small proportions of minerals, vitamins, leukocytes and somatic cells. However, recently studies reported additional components in porcine milk. Scientists have identified novel components of sow colostrum and milk, including exosomes, oligosaccharides, and bacteria [5-7]. These recently reported components play a possible vital role in stimulating development of the neonatal immune system and establishing intestinal bacterial communities. Since total piglets born has increased from 12 to 14 to $14-16$ per farrowing over the last few decades, it is important that sufficient essential nutrients for the piglets be produced by the prolific sow. Therefore, a systematic review regarding empirical and novel components of porcine milk will help to better understand the nutritional and biological functions in production of milk by sows.

Different from porcine milk, bovine milk is a biological fluid used for human food. The function of the bovine mammary gland has been well studied for many years. However, unlike bovine lactation, some of the important functions of the porcine mammary gland have been only 
recently reported in published literatures, such as: 1) mechanisms for glucose transfer into the mammary gland and subsequent synthesis of lactose; 2) the potential amino acid transporters in the porcine mammary gland for amino acid accumulation; and 3) fatty acid synthesis in the porcine mammary gland. Therefore, we summarized the recent research progress in porcine mammary gland function in this review, especially macronutrient (lactose, protein and fatty acids) transfer and synthesis mechanisms. The effects of nutrition, hormones, and environment on porcine milk synthesis have been thoroughly reviewed by Farmer and Quesnel [8], and will not be discussed in this review.

\section{Composition of protein, fat, and lactose in sow milk}

Similar to other mammals, protein, fat, and lactose are the three predominant components in sow milk (except water). Previously, Jensen [9] thoroughly summarized milk components of more than 30 mammals (Additional file 1: Table S1). The medians of protein, fat, and lactose concentrations among the different mammals are 5.85\%, $5.4 \%$ and $4.6 \%$, respectively. Sows appear to have comparatively higher milk fat concentration than the median mammal level, but not milk protein or lactose. With the recent enhancement of reproductive performance in sows, we hypothesized higher level of macronutrient components in porcine milk. However, milk macronutrient components do not significantly increase with enhanced reproductive performance in sows as depicted in Fig. 1; current concentrations of protein, fat and lactose in colostrum are similar to those of 30 years ago (16\% protein, 3\% lactose and 5\% fat) (as shown in Additional file 1: Table S2). Only minor changes in sow milk have been observed over the past 30 years (as shown in Additional file 1: Table S3). Recent research has reported relatively higher levels of fat ( $7.5 \%$ vs. $6.5 \%)$, lower levels of lactose (5\% vs. $6 \%)$ and similar protein expression (5\%). It was demonstrated that litter size does not regulate total sow milk yield using 'weigh-suckle-weigh' estimates of milk yield [10]. This indicates that nutrient intake of piglets from large litters can be restricted, as they receive less milk with similar quality. Therefore, provision of milk replacer for neonates in prolific sows might be an effective way to sustain their survival rate and weaning weight.

\section{Progress in porcine milk components}

\section{Porcine milk oligosaccharides}

Porcine milk oligosaccharides (PMOs) are composed of 3-10 monosaccharides bonded through glycosidic bonds. PMOs are not easily digested and they have anti-infective and prebiotic functions in piglets [11-13]. Milk oligosaccharides are widely found in humans (more

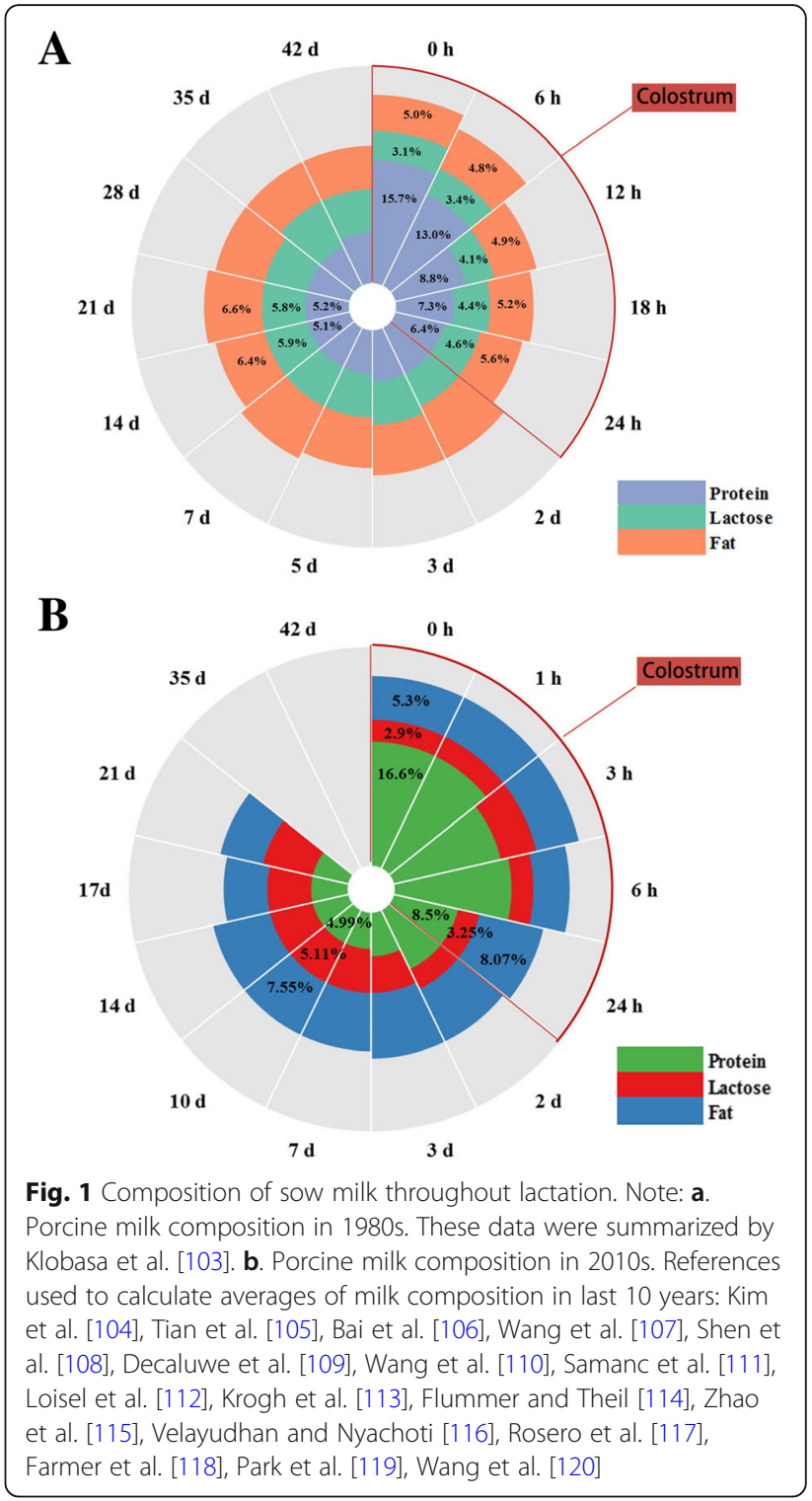

than 200 determined and 115 identified) and bovines (about 40 determined and 25 identified) [14-18]. PMOs in porcine milk have received little attention until recently. Tao et al. [5] identified nearly 30 different PMOs in porcine milk. They further demonstrated that the prevalent PMO in porcine milk is sialylated oligosaccharides, most containing 3-8 monosaccharides (e.g., glucose, galactose, $\mathrm{N}$-acetylglucosamine, $\mathrm{N}$-acetylneuraminic acid, and N-glycolylneuraminic acid). Recently, 13 and 25 novel PMOs in sow milk were identified by Difilippo et al. [19] and Wei et al. [20], respectively. Currently, more than 90 oligosaccharides in sow milk have been reported [20]. PMOs can be divided into neutral-, sialyl- and fucosyl-PMOs. Sialylated and neutral PMOs appear to be the dominant PMOs in sow milk, especially in colostrum $[5,20]$. The variation in specific PMOs among different 
studies might be associated with different test methods. As presented in Table 1, neutral PMOs accounted for about $70-80 \%$ of total PMOs in Yorkshrie, while sialylated PMOs were the dominant PMOs (60-80\% of total PMOs) in Landrace. Although the data are still quite limited and obtained in different survey for the different breeds, these reports indicate PMOs could be significantly variable among different breeds.

PMO content was reported highest in colostrum, gradually decreasing during early lactation, but increased at $24 \mathrm{~d}$ [5]. Furthermore, proportions of specific PMOs change with the progress of lactation. PMOs in porcine milk are parity dependent and more abundant in the gilt (females pig who has not farrowed or given birth to a litter previously) than the sow (females pig who has farrowed or given birth to a litter previously). High concentrations of PMOs might partly compensate for deficiencies in milk volume in colostrum [20]. Furthermore, high PMO concentrations in the mammary gland might protect the gilt mammary gland from bacterial infection. Although PMOs are resistant to digestion in the small intestine, they are fermentable substrates in the large intestine, which is evident because few PMOs are found in the feces of neonatal piglets [19]. These oligosaccharides can be fermented into short chain fatty acids (SCFAs) including butyric acid which has been widely demonstrated to participate in regulation of mucosal immunity, gut integrity, and colonic health [21-23]. PMOs can also prevent pathogens from adhering to the mucosa since they contain analogues to various receptors for microbes [24, 25]. These oligosaccharides also have been reported to selectively stimulate growth of beneficial bacteria $[11,12]$, which might be related to their fucosylated and sialylated structures [13]. Thus, oligosaccharides appear to have beneficial biological functions for piglets. Future studies need to clarify whether artificial oligosaccharides can be used as feed additives in the weaning pig diet. Currently, limited data are available on the impact of the sow genotype on PMO composition in colostrum and milk. A better understanding of these variations is vitally important for efficient pig

Table 1 Porcine milk oligosaccharides of Yorkshire and Landrace in colostrum and milk (\%)

\begin{tabular}{llllll}
\hline Breeds & Source & $\begin{array}{l}\text { Neutral } \\
\text { OS }\end{array}$ & $\begin{array}{l}\text { Acidic- } \\
\text { sialylated } \\
\text { OS }\end{array}$ & $\begin{array}{l}\text { Neutral- } \\
\text { fucosylated } \\
\text { OS }\end{array}$ & References \\
\hline Yorkshire & Colostrum & 69 & 16 & 2 & {$[121]$} \\
& $\begin{array}{l}\text { Transitional } \\
\text { milk }\end{array}$ & 76 & 19 & 3 & \\
& Mature milk & 81 & 29 & 4 & \\
Landrace & Colostrum & 22 & 78 & 1 & [20] \\
& $\begin{array}{l}\text { Transitional } \\
\text { milk }\end{array}$ & 18 & 74 & 7 & \\
& Mature milk & 33 & 58 & 9 & \\
\hline
\end{tabular}

production. Furthermore, mammary glands are susceptible to infection during lactation and the relationship of PMOs to immunity from mammary infection is largely unknown, suggesting a need for future research.

\section{Exosomes}

Extracellular vesicles are a heterogeneous group of cell-derived membranous structures comprised of exosomes and microvesicles, which are present in biological fluids and involved in multiple physiological processes [26]. Exosomes, nanosized endosome-derived membrane vesicles $(40-100 \mathrm{~nm}$ in diameter), were found in porcine milk in recent studies [6, 27]. These vesicles contain mRNA, microRNA (miRNA), DNA, proteins, and lipids and can possibly transfer these bioactive components to neonatal pigs [28-30]. It has been reported that 16,304 mRNAs, 237 miRNAs and 639 proteins have been identified in porcine milk exosomes by RNA-sequencing and proteomic analysis and predicted to be involved in immunity, proliferation and cellular signaling [30]. miRNAs have been the predominant focus of most recent research. Milk miRNAs in exosomes are stable to intestinal digestion and permeable to the intestinal barrier [31]. Although the functions of exosomes are still controversial, some studies hypothesized that exosomal miRNAs could be transferred from maternal milk to neonates via the digestive tract, participating in regulating the neonatal immune system [27, 32] and simulating gastric/pancreatic digestion [33]. Studies focusing on the function of exosomes in porcine milk are very limited. Chen et al. [34] found porcine milk exosomes can regulate intestinal cell proliferation and digestive tract development. However, whether exosomes have an important role in neonatal growth and regulate neonatal immunity needs to be verified in in vivo models. It is apparent that our knowledge regarding porcine milk exosomes is quite limited. Future studies need to clarify the following: stability of the components of porcine milk exosomes through lactation (colostrum, transitional milk and mature milk); identification of core functional components of porcine milk exosomes in addition to miRNAs; and regulation of porcine milk exosomes through nutrition, conventional breeding, and genetics.

\section{Bacteria in milk}

Milk has been identified as an excellent source of probiotic lactic acid bacteria for neonates in humans and cows [35-37]. These lactic acid bacteria might originate from the maternal intestine, translocate to breast milk through the bloodstream, and subsequently colonize the gastrointestinal tract of neonates [38]. Recently, Martin et al. [7] reported some strains displayed high probiotic potential in sow milk, such as Lb. reuteri CR20 (a reuterin-producing strain), Lb. salivarius CELA2 (a 
bacteriocin-producing strain) and $L b$. paraplantarum CLB7. However, it is well-known that milk is also a good culture medium for bacteria from environmental sources. For example, the teat surface can contain a high diversity of bacteria $[39,40]$. Therefore, existence of the bacterial entero-mammary pathway needs further confirmation. Further research needs to clarify whether the source of bacteria is from the sow, environmental sources, or both. However, there is potential for beneficial bacteria in milk to be developed into a feed additive for weaning piglets.

\section{Leukocytes in milk}

Traditionally, it has been thought that immunoglobulins in colostrum are the only source of adaptive immunity from sow to piglets. However, leucocytes in sow milk can also be a source of immunity. The average proportion of leucocytes in colostrum is $1 \times 10^{7}$ cells $/ \mathrm{mL}$, which decreases to $1 \times 10^{6}$ cells $/ \mathrm{mL}$ in sow milk [41], similar to human milk [42]. In sow milk, leucocytes are primarily composed of neutrophils, macrophages and lymphocytes, common components in milk. Neutrophils have been regarded as the final effector cells of an acute inflammatory response and mainly participate in the clearance of extracellular pathogens. Research has demonstrated that neutrophils are involved in the activation, regulation, and effector functions of innate and adaptive immune cells [43]. Recently, lymphocyte subsets in sow milk have been identified by Pomorska-Mol et al. [44], consisting mainly of T-lymphocytes, B-lymphocytes, T-helper lymphocytes, and T-cytotoxic lymphocytes. Activated $\mathrm{T}$ cells from sows could compensate for the immature function of neonatal $\mathrm{T}$ cells and promote their maturation [45]. Macrophages are widely known for phagocytic activity and also participate in regulation of the function of neonatal $\mathrm{T}$ and $\mathrm{B}$ cells and in secretion of immunoregulatory factors [46]. However, even though leukocytes exist in milk, the phagocytic capacity of colostrum and milk leukocytes was reported to be weak compared with blood leukocytes [47]. Thus, leukocytes in porcine milk are more likely important immunity regulators rather than phagocytic cells.

\section{Hormones in milk}

Hormones existing in sow blood can be transported and secreted into milk through the mammary gland. These bioactive compounds in milk can play important roles in mammary cell regulation and neonatal function (gastrointestinal tract or systemic) [48]. IGF-I and IGF-II are present in both sow colostrum and milk. Concentrations of IGF-I have been reported as $136 \mathrm{ng} / \mathrm{mL}$ and 10-14 $\mathrm{ng} /$ $\mathrm{mL}$ in colostrum and milk, respectively [49]. Published estimates of IGF-II levels are higher than IGF-I with values of $291 \mathrm{ng} / \mathrm{mL}$ and 11-29 $\mathrm{ng} / \mathrm{mL}$ in colostrum and milk, respectively [49]. Correspondingly, IGF binding proteins (IGFBP) are also present in porcine milk [49]. Another hormone found in porcine milk is insulin. Similar to IGF-I and IGF-II, the concentration of insulin is high at the beginning of lactation (about $400 \mu \mathrm{U} / \mathrm{mL}$ ), then decreases to approximately $30 \mu \mathrm{U} / \mathrm{mL}$ [50]. Also, recent studies have found that relaxin is delivered from mother to offspring via the consumption of colostrum $(9-19 \mathrm{ng} / \mathrm{mL})$ and milk (2 $\mathrm{ng} / \mathrm{mL}$, postnatal $14 \mathrm{~d})$ [51, 52]. These observations support a role for relaxin as a lactocrine mediator in the development of the neonatal pig. Other growth-stimulating factors, such as epidermal growth factor (EGF), have also been detected in sow milk [53].

Hormone receptors for insulin, prolactin and IGF-I were reported to be expressed in the porcine mammary gland, which further demonstrates that these hormones have important biological functions in the mammary gland [54]. Despite the potential vital functions of hormones in milk, most of the research reports that focus on hormones in milk are from approximately 20 years ago. This may be because hormones are relatively low in milk compared with those in blood and not considered metabolically important. Secondarily, it is difficult to detect hormones in milk and especially colostrum because of their viscosity and a large number of hormones are binding to casein. However, it is important to not ignore the function of hormones in milk, because they can play a vital role even in small concentrations.

\section{Other metabolites}

Recently, 25 metabolites were identified in colostrum, including monosaccharides, disaccharides (such as lactose), organic acids (lactate, citrate, acetate and formate), nitrogenous organic acids (such as creatine) and other compounds (including nucleotides) [55]. Similar to porcine milk glycemics, it was reported that colostrum metabolome is greatly affected by different breeds (colostrum composition of Duroc sows differ from Landrace and Large White sows) [55]. Interesting, this study found some biomarkers are positively-related (acetate and taurine) or negatively-related (dimethylamine and cis-aconitate) to litter weight gain [55].

\section{Recent progress in mammary gland function} Glucose uptake and lactose synthesis

Glucose is an important precursor to some of the constituents of milk, despite low concentrations in sow milk. Approximately 59\% of plasma glucose transported into the mammary gland contributes to lactose in sow milk, while the remaining glucose is converted into glycerol, casein, albumin, and oxidized into $\mathrm{CO}_{2}[56,57]$. Consequently, transportation of glucose into the mammary gland is a critical step in milk synthesis. Glucose transportation into the mammary gland is a complicated 
process requiring coordination of a variety of membrane proteins, but the specific proteins involved differ among species. In the bovine mammary gland, dominant glucose transporters are glucose transporter-1 (GLUT1) and GLUT8, and sodium-dependent glucose cotransporters 1 (SGLT1), SGLT2 and GLUT12 are also expressed. [58-60]. In rats, GLUT1, SGLT1, GLUT12 appear to play a vital role in glucose transport to the mammary gland [61, 62]. Compared with literature for bovine and rats, reports focusing on the glucose transport system of lactating sows are limited. Chen et al. [63] reported mRNA abundance for glucose transporters GLUT1, GLUT8, SGLT1, SGLT3, and SGLT5 in the mammary gland. The mRNA abundance of GLUT1 was at least 10 times more abundant compared to other glucose transporters with high protein expression [63]. Furthermore, a significant increase was reported in the mRNA level of GLUT1 and SGLT1 after sows progressed from gestation to peak lactation [63], which is consistent with other reports [64]. These studies indicate that GLUT1 could be the most important transporter in the porcine mammary gland. However, only mRNA levels of other glucose transposers are generally available in the literature. To clarify the specific function of each glucose transporter, future research is needed to evaluate the protein abundance of these glucose transporters and localize their position in the porcine mammary gland by immunofluorescence microscopy or confocal microscopy. Also, CRISP-Cas9 could be used to knock-out these transport genes and determine their effects on glucose transportation from plasma to cellular fluid or cellular fluid to Golgi bodies.

Glucose is largely converted into lactose after it is transferred into the mammary gland. Lactose synthesis requires the coordination of many genes or proteins including phosphoglucomutase 1 (PGM1), UDP-glucose pyrophosphorylase 2 (UGP2), galactose-1-phosphate uridylyltransferase (GALT), and UDP-galactose-4-epimerase (GALE) (interconversion of glucose and galactose), SLC35A2 (transportation of UDP-galactose into Golgi bodies), $\alpha$-lactalbumin (LALBA) and $\beta$-1,4-galactosyltransferase-1 (B4GALT1) (under which glucose and UDP-galactose

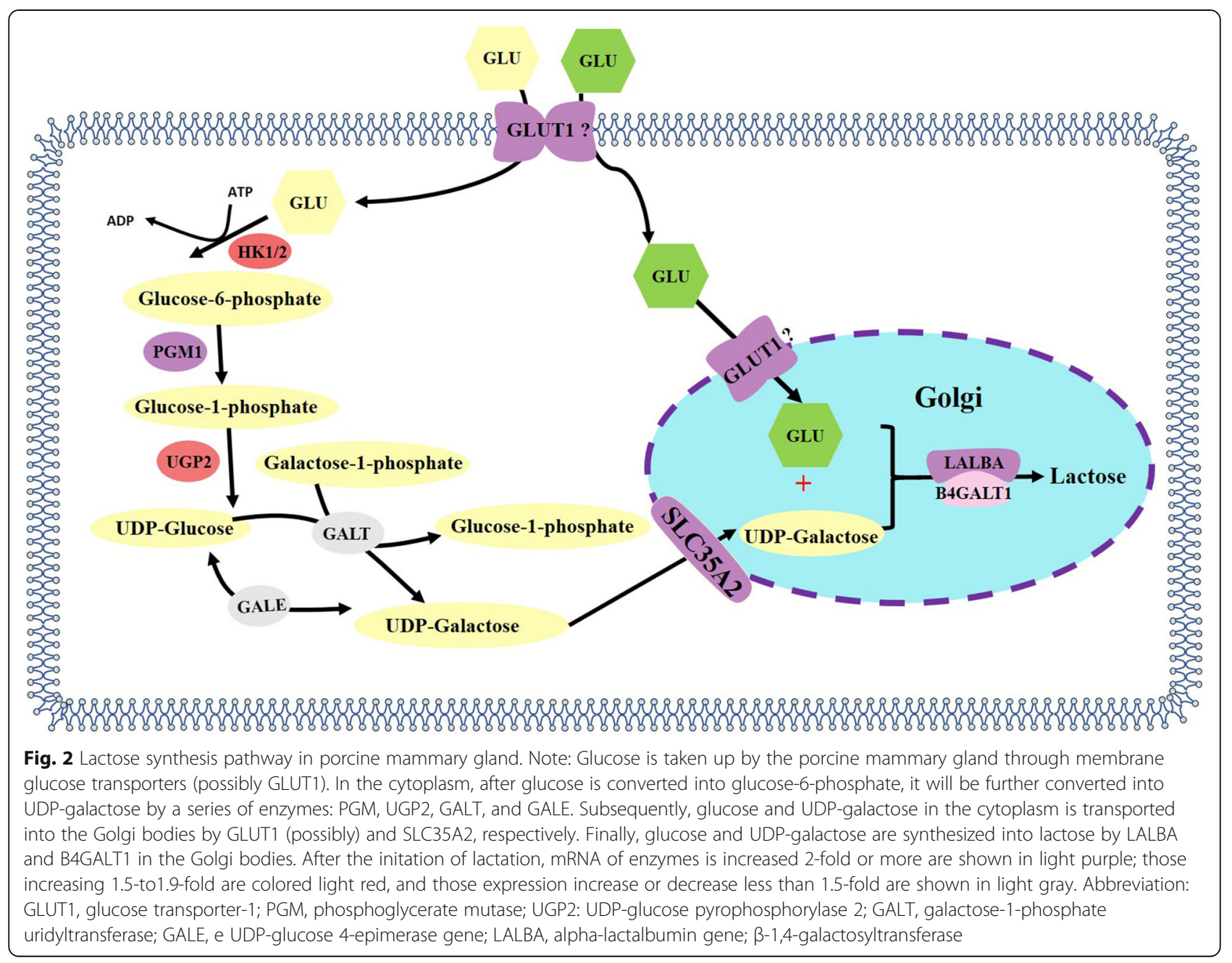


synthesize lactose) [65-67]. However, most reports in the literature focus on lactose synthesis in rat, bovine, goat and human models. In lactating sows, the critical genes regarding lactose synthesis have only recently been reported. Chen et al. [63] reported that the gene and protein expression of B4GALT1 significantly increased in sows' mammary glands from late pregnancy to peak lactation. B4GALT1 encodes type II membrane-bound glycoprotein, specifically $\beta-1$, 4-galactosyltransferase 1 , lactose synthetase, which can transfer galactose to acceptor sugars [68]. Coincidently, Zhang et al. [69] also found the mRNA and protein expression profiles of B4GALT1 increased significantly during the entirety of lactation in sows Furthermore, the increased mRNA and protein expression of LALBA was also observed in their research. $\alpha$-lactalbumin, one of milk whey proteins, can facilitate the glucose identification and banding of B4GALT1, and improve the B4GALT1 activity by at least 30-fold [70-73]. These research reports of lactose synthesis in sows indicated that $L A L B A$ and $B 4 G A L T 1$ are the critical genes or steps in the lactose synthesis pathway of the sow. LALBA and B4GALT1 are also highly conserved in humans [74], cows [75], goats [76] and other species. and have critical functions in lactose synthesis. Current knowledge about possible mechanisms of lactose synthesis in the porcine mammary gland is presented in Fig. 2.

\section{Amino acid uptake and protein synthesis}

The mammary gland requires large amounts of amino acids for the synthesis of milk protein. Differences in amino acid concentrations in the veins and arteries of lactating mammary glands suggest that the mammary gland extracts essential amino acids primarily from the blood. Amino acid uptake by the porcine mammary gland can be divided into three levels: high level (dose > $30 \mathrm{~g} / \mathrm{d}$; leucine, arginine and lysine), middle level (15 g/ $\mathrm{d}<$ dose $<30 \mathrm{~g} / \mathrm{d}$; valine, isoleucine, threonine, phenylalanine), and low level (dose $<15 \mathrm{~g} / \mathrm{d}$ tyrosine and methionine and histidine) [77, 78]. Presently, the amino acid transporter system in the mammary gland is not well-understood, but information suggests that the mammary gland has a transport system similar to other organs (intestine, kidney, placenta). As presented in Table 2, the porcine mammary gland expresses cationic amino acid transporters (CAT-1 (SLC7A1), CAT2-B (SLC7A2)), neutral amino acid transporters (ASCT1 $(S L C 1 A 4))$ and transporters for both cationic and neutral amino acids $\left(b^{0,+} A T\right.$ (SLC7A9), ATB ${ }^{0,+}$ (SLC6A14), $y^{+} L A T 2$ (SLC7A6)) [79-81]. $A T B^{0,+}$ and $A S C T 1$ are significantly increased at peak lactation [80]. Our lab reported that either $E A A C 1$ or EAAT3 (SLC1A1) is the predominant anionic amino acid transporter and is significantly increased during lactation [82]. Cationic amino acid transporters CAT-1,
Table 2 Predominant amino acids transporters identified in porcine mammary glands

\begin{tabular}{cccl}
\hline Systems & Proteins & Genes & Substrates \\
\hline \multicolumn{2}{c}{ Cationic amino acid transporters } & \\
CAT1 & SLC7A1 & Arg, Lys, His \\
CAT2-B & SLC7A2 & Arg, Lys, His \\
Neutral amino acid transporters & \\
ASCT1 & SLC1A4 & Ala, Ser, Cys \\
ASCT2 & SLC1A5 & Ala, Ser, Cys, Thr, Gln \\
LAT2 & SLC7A8 & Leu, Ile, Val, Trp \\
SNAT2 & SLC38A2 & Gly, Pro, Ala, Ser, Cys, Gln, Asn, \\
& & Ser, Met
\end{tabular}

Cationic and neutral amino acid transporters

$\begin{array}{cll}y^{+} \text {LAT1 } & \text { SLC7A7 } & \text { Lys, Arg, Gln, His, Met, Leu } \\ y^{+} \text {LAT2 } & \text { SLC7A6 } & \begin{array}{l}\text { Lys, Arg, Gln, His, Met, Leu, Ala, } \\ \text { Cys }\end{array} \\ \text { b }^{0,+} \text { AT } & \text { SLC7A9 } & \text { Arg, Lys, Cys } \\ \text { ATB }^{0,+} & \text { SLC6A14 } & \text { All neutral and cationic amino acids }\end{array}$

Anionic amino acid transporters

EAAT3 SLCIA1 Glu, Asp

Note: References reporting amino acid transporters in porcine mammary gland: [79-81]

$C A T 2-B, y^{+} L A T 1$ and $y^{+}$LAT2 are widely expressed in the mammary gland and $y^{+} L A T 2$ is significantly increased at peak lactation [82]. Neutral amino acid transporters ASCT1, ASCT2, LAT2 (SLC7A8) and SNAT2 (SLC38A2) are also expressed in the mammary gland [82]. Recently, a significant increase of $B^{0,+} A T$ and $C A T-4$ were observed in swine mammary gland during the transition from colostrogenesis to lactation [83]. However, compared with mRNA expression of amino acid transporters between $\mathrm{d} 4$ and 14 of lactation, different stage of lactation did not influence the abundance of these mRNA, except for $A T B^{0,+}$, which was $28 \%$ lower on d 14 compared with d 4 of lactation. This indicates that the sow mammary gland significantly expresses amino acid transporters as early as $4 \mathrm{~d}$ [84]. Currently, there is little information regarding the location (apical surface, basolateral surface or cytoplasm) of amino acid transporter proteins within porcine and other species' mammary glands.

Mammary gland epithelial cells transport free amino acids from blood through the basolateral surface and synthesize them into milk protein in the mammary gland. It has been reported that free amino acid concentrations in porcine milk are very low [85]. Therefore, we hypothesize the functional amino acid transporters should exist on the basolateral side. Consistent with this hypothesis, some amino acid transporters such as: $\mathrm{y}^{+} \mathrm{LAT} 1 / 4 \mathrm{~F} 2 \mathrm{hc}$ and $\mathrm{y}^{+} \mathrm{LAT} 2 / 4 \mathrm{~F} 2 \mathrm{hc}$ are expressed in the basolateral cell membrane in other organs [86, 87]. However, most of the amino acid transporters expressed 
in the mammary gland ( $\mathrm{ATB}^{0,+}, \mathrm{b}^{0,+} \mathrm{AT}, \mathrm{CAT}-1$ and etc.) are localized only at the apical pole of cells in other organs (e.g., intestinal and kidney cells). This might due to diversity of the location of these amino acid transporters among different cell types. For example, EAAT3 was predominantly located in the basolateral cell membrane in pigmented epithelial cells, while it was mainly identified on the apical surface in Madin-Darby canine kidney cells [88]. Therefore, future research should use confocal immunofluorescence to localize these amino acid transporters. Furthermore, within $24 \mathrm{~h}$ after parturition, large amounts of immunoglobins are directly transferred from blood to milk instead of their components amino acids [89] . This process might rely on the neonatal Fc receptor (FcRn) expressed in the porcine mammary gland [90].

After uptake of free amino acids from blood into the porcine mammary gland, they are synthesized into milk protein, including caseins and whey proteins. The caseins in porcine milk contain $\alpha_{\mathrm{S} 1}$-casein (CSN1S1), $\alpha_{\mathrm{S} 2}$-casein (CSN1S2), $\beta$-casein (CSN2), and
K-casein (CSN3) [91]. It has been demonstrated that CSN2, CSN1S1 and CSN1S2 are the most abundant three genes related to protein synthesis in the porcine mammary gland [92]. Except for caseins, the remaining proteins are whey proteins, which are mainly composed of $\beta$-lactoglobulin (BLG), $\alpha$-lactalbumin (LALBA) and whey acidic protein (WAP) [91]. The possible mechanism of the amino acid transporter and protein synthesis system is summarized in Fig. 3. Recently, Hurley [93] comprehensively summarized reports of the concentrations of all the components of whey protein, which are listed in Fig. 4. Furthermore, maternal immunoglobulins also belong to milk whey proteins, and play a vital role in maternal immunity for neonates. The shift of immunoglobulin levels in the porcine mammary gland during the entirety of lactation period is well documented in previous research [94]. In colostrum, all IgG and nearly $80 \%$ of IgM are derived from the serum of the sow. Immune cells that migrate to the

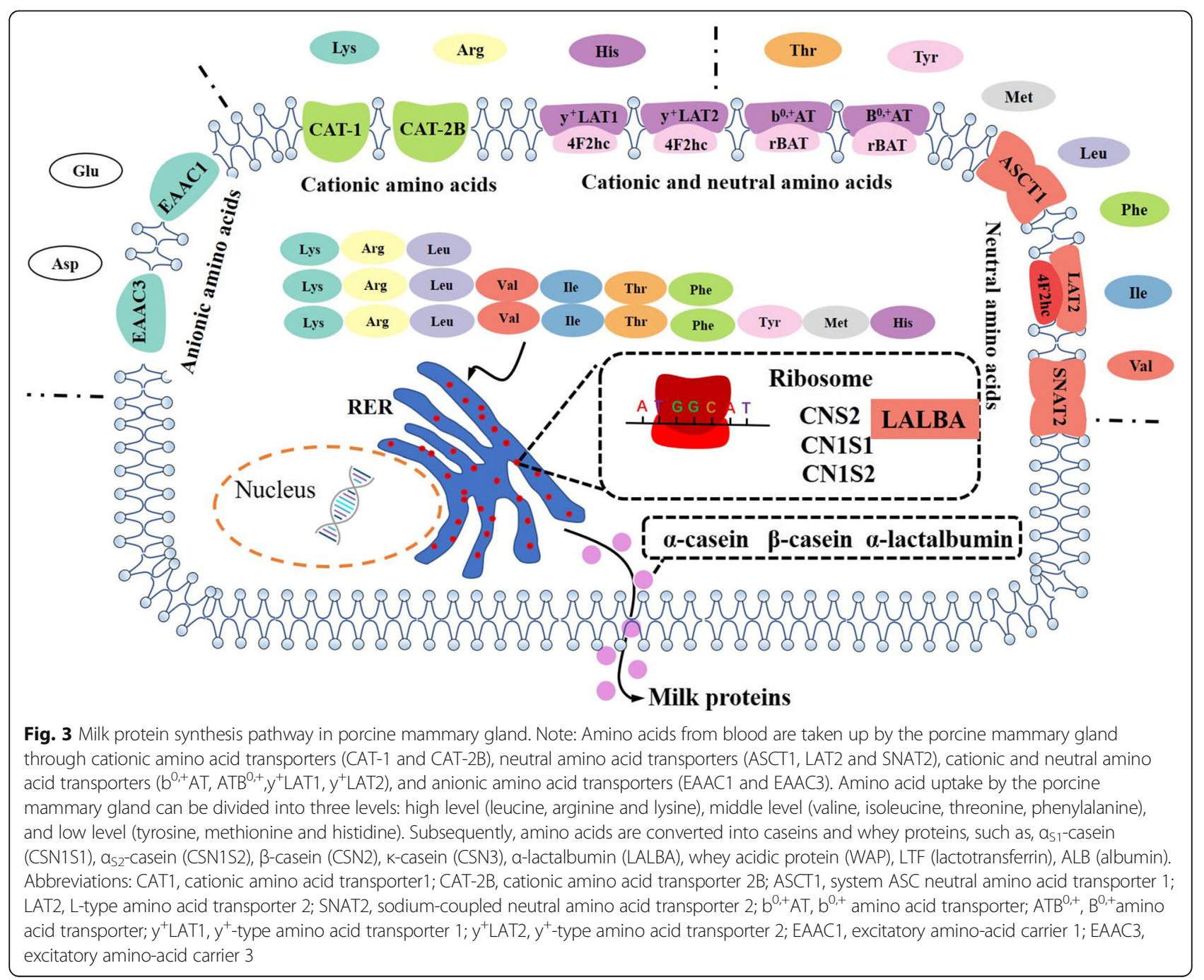




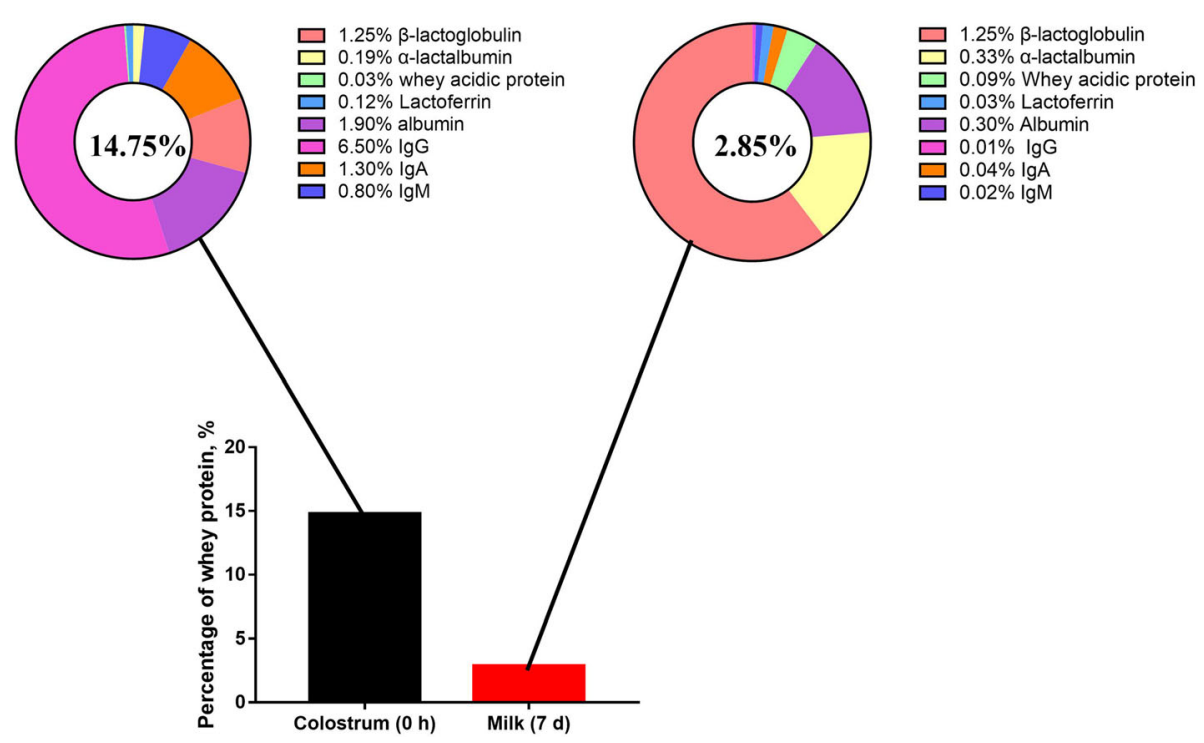

Fig. 4 Components of whey protein in colostrum and milk. Note: Data are summarized from the information provided by Hurley [93]

mammary gland contribute around $90 \%$ of $\operatorname{IgA}$ and IgM, and 70\% IgG in milk [89].

\section{Fatty acid transportation}

The mechanisms involved in fatty acid uptake by porcine mammary epithelial cells are still largely unknown. It was reported that cellular fatty acid uptake might be modulated by intracellular fatty acid-binding proteins (FABPs). Currently, 9 isoforms of fatty acid binding proteins have been identified [95]. FABP3 is predominantly expressed in bovine and dairy goat mammary glands during lactation compared with other FABP isoforms [96, 97]. However, FABP4 was reported to be significantly associated with fatty acid uptake in the bovine mammary gland [98]. Inhibition of FABP3 has been reported to reduce the synthesis of medium-chain fatty acids in the goat mammary gland [99]. Recently, FABP3 was detected in the porcine mammary gland and is primarily expressed during lactation [100]. However, $\mathrm{Lv}$ et al. [100] did not attempt to identify other FABP isoforms in the porcine mammary gland. We could not find any information that indicated that FABP3 is the only FABP isoform that exists in the porcine mammary gland. Therefore, future studies are needed to clarify other potential FABP isoforms in the porcine mammary gland. Milk from cattle contains short, medium and long chain fatty acids $[101,102]$ while fatty acid profiles in sow's milk are mainly composed of long-chain fatty acids. The profiles of major fatty acids in sow colostrum and milk are listed in Table 3. The major fatty acids in sow colostrum and milk are C14:0,
C16:0, C16:1 (n-7), C18:0, C18:1(n-9) and C18:2 (n-6). The literature reporting sow fatty acid concentrations is limited, but it is reasonable to conclude that sow milk contains relatively high levels of C14:0, C16:0 and C16:1 $(n-7)$ and low levels of C18: $2(n-6)$ compared to colostrum.

After uptake into the mammary gland, free fatty acids will be converted into triacylglycerol (TAG). The process of TAG synthesis in the porcine mammary gland was reported by Lv et al. [100]. They found some of the critical genes involved in milk TAG synthesis and secretion, including those related to FA uptake, FA activation, intracellular transport, de novo FA synthesis, FA elongation, FA desaturation, TAG synthesis, lipid droplet formation, transcription factors and nuclear receptors (Table 4). A proposed mechanism of milk fat synthesis is summarized in Fig. 5.

Table 3 Major fatty acid profiles in colostrum and milk (mg/g)

\begin{tabular}{llllll}
\hline Fatty acids & \multicolumn{2}{l}{ Colostrum } & & \multicolumn{2}{l}{ Milk } \\
\cline { 2 - 3 } \cline { 6 - 6 } & $0 \mathrm{~d}$ & $10 \mathrm{~d}$ & & $17 \mathrm{~d}$ & $22 \mathrm{~d}$ \\
\hline C14: 0 & 1.41 & 3.08 & & 3.34 & 3.93 \\
C16: 0 & 19.73 & 28.82 & & 27.96 & 33.46 \\
C16: 1 & 2.77 & 6.87 & 8.02 & 10.05 \\
C18: 0 & 4.66 & 4.95 & & 4.13 & 4.14 \\
C18: 1 & 29.11 & 32.53 & 27.21 & 29.48 \\
C18: $2(n-6)$ & 20.91 & 22.01 & 13.20 & 17.52 \\
\hline
\end{tabular}

Note: References used to calculate percentage of fatty acids: Bai et al. [106]; Amusquivar et al. [122]; Bee [123] 
Table 4 Critical genes involved in fatty acid synthesis in porcine mammary gland

\begin{tabular}{ll}
\hline Functions & Genes \\
\hline FA uptake & Very low density lipoprotein receptor, lipoprotein Lipase, fatty acid translocase/CD36 \\
FA activation & Acyl-CoA synthetase short-chain family member 2, Acyl-CoA synthetase long-chain family member 3 \\
Intracellular transport & Fatty acid-binding protein 3 \\
De novo FA synthesis & Acetyl-CoA carboxylase alpha, fatty acid synthase \\
FA elongation & Elongation of very-long-chain fatty acids 1 \\
FA desaturation & Stearoyl-CoA desaturase, fatty acid desaturase 1 \\
TAG synthesis & Glycerol-3-phosphate acyltransferase, 1-acyl-sn-Glycerol-3-phosphate acyltransferase 1, lipin 1, Diacylglycerol \\
& acyltransferase 1 \\
Lipid droplet formation & Butyrophilin, dehydrogenase, adipophilin 2 \\
Transcription factors and nuclear & Sterol response element binding protein 1, Cleavage-activating protein, insulin induced gene 1 or 2 \\
receptors &
\end{tabular}

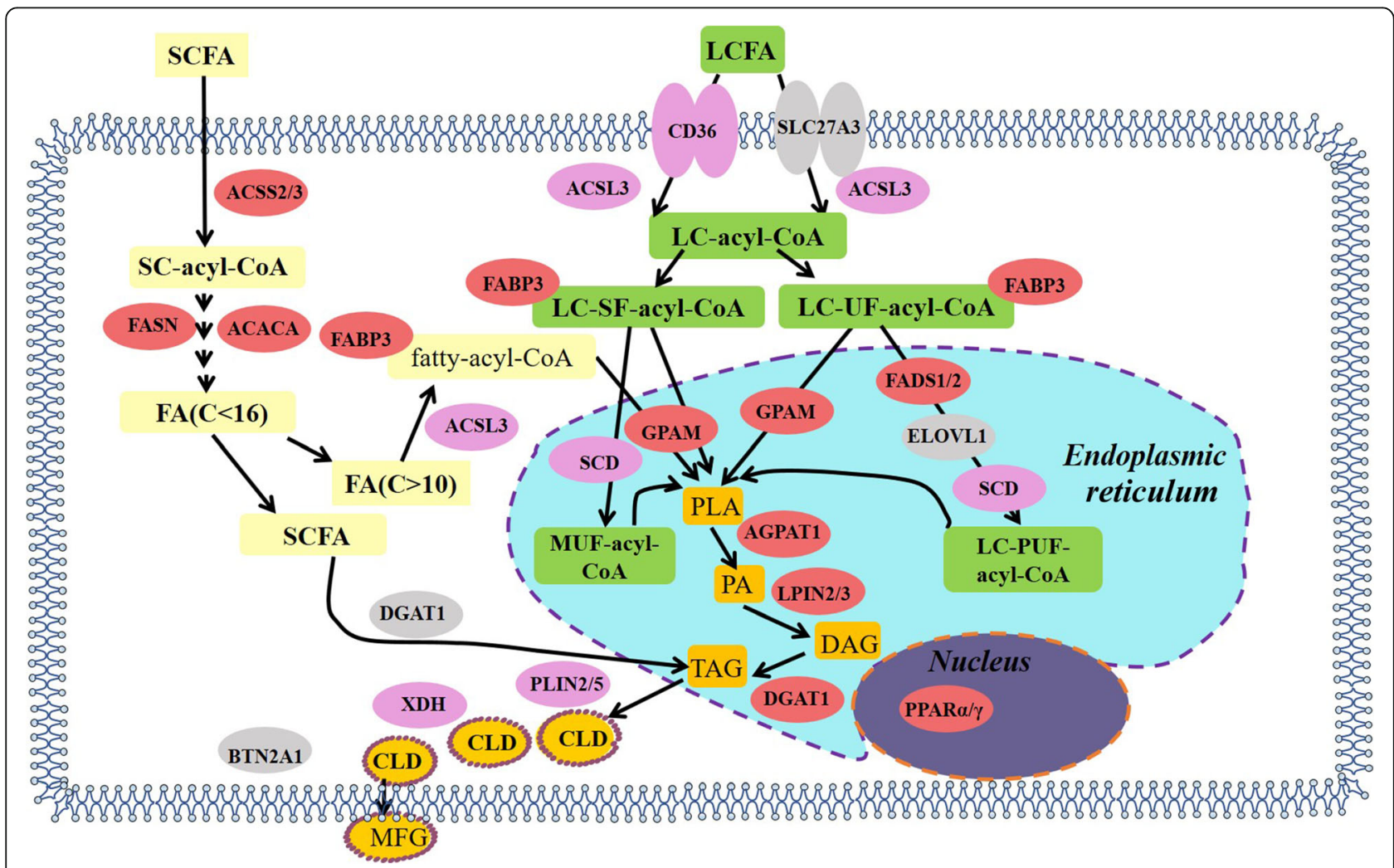

Fig. 5 Lipid synthesis pathway in porcine mammary gland. Note: LCFA the enter porcine mammary gland, facilitated by transport proteins (mainly CD36), and are converted into their activated form LC-acyl-CoA, with the help of ACSL. Cytosolic LC-acyl-CoA is transported to the endoplasmic reticulum membrane by FABP3 and esterified there to glycerol-3-phosphate to produce LPA by GPAM. In the endoplasmic reticulum, PA can be hydrolyzed with LPIN to form DAG, which then is acylated to form TAG by DGAT. Newly-formed TAG forms cytoplasmic lipid droplets in the ER membrane via incorporation. The cytoplasmic lipid droplets are then transported to the apical membrane, and eventually released into porcine milk. A series of enzymes are required to facilitate this process, of which FASN and ACACA are considered the crucial enzymes of cellular fatty acid de novo synthesis. ACACA carboxylates acetyl-CoA to form malonyl-CoA, which is further converted by FASN to fatty acids $(C \leq 16)$. The synthesized fatty acids then participate in TAG formation. After the initation of lactation, mRNA of enzymes is increased 5fold or more are shown in light purple; those increasing 2-fold or more are colored light red, and those expression increase or decrease less than 2-fold are shown in light gray. Abbreviations: ACACA, acetyl-CoA carboxylase alpha; ACSL3, acyl-CoA synthetase long-chain family member 3; ACSS2, acyl-COA synthetase short-chain family member 2; AGPAT6, 1-acyl-sn-glycerol-3-phosphate acyltransferase 6; CD36, fatty acid translocase/ CD36; CLD, cytoplasmic lipid droplet; DAG, diacylglycerol; DGAT1, diacylglycerol acyltransferase 1; FABP3, fatty acid binding protein 3; FASN, fatty acid synthase; GPAM, glycerol-3-phosphate acyltransferase, mitochondrial; LCFA, long chain fatty acid; LPA, lysophosphatidic acid; LPIN2, lipin 2; MFG, milk fat globule; PA, phosphatidic acid; PLIN2, perilipin 2; PPARY, peroxisome proliferator-activated receptor $\gamma$; SCFA, short chain fatty acid; SCD, stearoyl-CoA desaturase; TAG, triacylglycerol 


\section{Conclusion}

Porcine milk is a highly complicated bio-fluid that nourishes neonates and protects them from pathogens and disease. In the past 30 years, the concentrations of major components (protein, fat and lactose) in colostrum seem quite stable and only minor changes were observed in fat and lactose concentrations in mature milk. Beside major nutrient components, recent research reported other vital bioactive components (oligosaccharides, exosomes, and bacteria) in porcine milk. These antimicrobial and immunomodulatory components of porcine milk are hypothesized to compensate for immature neonatal immune systems and mitigate environmental infectious pathogens. Understanding the nutritional and non-nutritional components in porcine milk is critical for efficient pig production. However, information and effects regarding these bioactive components in in vivo pig model is still limited. Some vital questions should be addressed in the future: 1) How do sow genotypes affect sow milk composition? 2) Do different oligosaccharides regulate the bacterial biome and immunity in the GI tract of piglets and protect sows' mammary glands from bacterial infection? 3) What is the source of the bacteria in milk, gut migration or contamination from milking? 4) Do exosomes regulate piglets' gut function?

Recent studies provide some preliminary data on the nutritional transporter and synthesis systems associated with the porcine mammary gland. Cited reports in this review provide some information on the expression of glucose, amino acid and fatty acid transporters and document potential milk lactose, protein and fat synthesis pathways in the mammary gland. In order to further study these nutritional transporters, these transporters need localized with immunofluorescence microscopy or confocal microscopy. Additionally, the biological effects of non-coding RNA (miRNA, circular RNA) on mammary gland transporter and synthesis systems are largely unknown. Understanding these nutrition transporter and synthesis systems might provide a rational approach to regulate milk composition in the future.

\section{Additional file}

Additional file 1: Table S1. Milk composition of different species (\%). Table S2. Averages and range of reported concentrations of protein, fat and lactose of sow colostrum in 2010s. Table S3. Averages and range of reported concentrations of protein, fat and lactose of sow milk in 2010 s. (DOCX $31 \mathrm{~kb})$

\section{Abbreviations}

ACACA: Acetyl-CoA carboxylase alpha; ACSL3: Acyl-CoA synthetase longchain family member 3; ACSS2: Acyl-CoA synthetase short-chain family member 2; AGPAT6: 1-acyl-sn-glycerol-3-phosphate acyltransferase 6;

ASCT1: System ASC neutral amino acid transporter $1 ; \mathrm{ATB}^{0,+}: \mathrm{B}^{0,+}$ amino acid transporter;; $b^{0,+} A T$ : $b^{0,+}$ amino acid transporter;; B4GALT: Beta-1, 4-galactosyl transferase; CAT1: Cationic amino acid transporter 1; CAT-2B: Cationic amino acid transporter 2B:" CD36: Fatty acid translocase/CD36; CLD: Cytoplasmic lipid droplet; DAG: Diacylglycerol; DGAT1: Diacylglycerol acyltransferase 1;
EAAC1: Excitatory amino-acid carrier 1; EAAC3: Excitatory amino-acid carrier 3; FABP3: Fatty acid binding protein 3; FASN: Fatty acid synthase; GALE: UDPglucose 4-epimerase gene; GALT: Galactose-1-phosphate uridyltransferase; GLUT: Glucose transporter; GPAM: Glycerol-3-phosphate acyltransferase, mitochondrial; LALBA: Alpha-lactalbumin gene 31,4-galactosyltransferase.; LAT2: L-type amino acid transporter 2; LCFA: Long chain fatty acid; LPA: Lysophosphatidic acid; LPIN2: Lipin 2; MFG: Milk fat globule; PA: Phosphatidic acid; PGM: Phosphoglycerate mutase; PLIN2: Perilipin 2; PMOs: Porcine milk oligosaccharides; PPARy: Peroxisome proliferatoractivated receptor $\gamma$; SCD: Stearoyl-CoA desaturase; SCFA: Short chain fatty acid; SGLT: Sodium-dependent glucose cotransporter; SNAT2: Sodiumcoupled neutral amino acid transporter 2; TAG: Triacylglycerol; UGP2: UDPglucose pyrophosphorylase $2 ; \mathrm{y}^{+} \mathrm{LAT} 1$ : $\mathrm{y}^{+}$-type amino acid transporter 1 ; $\mathrm{y}^{+}$LAT2: $\mathrm{y}^{+}$-type amino acid transporter 2

\section{Acknowledgements}

The author would like to thank Dr. M. A. Brown for his language editing help.

\section{Ethical approval}

All procedures used in experiments of our lab were performed in accordance with the Institutional Animal Care and Use Committee (SCAUAEC-2010-0416) at the South China Agricultural University.

\section{Funding}

This study was funded by the National Key R\&D Program of China (No. 2018YFD0500600) and the Natural Science Foundation of Guangdong Province (No. 2018A030310201).

Availability of data and materials

Please contact author for data requests.

\section{Authors' contributions}

SZ initiated the idea, the scope, and the outline of this review paper. SZ, FC, $Y Z, Y L, M T, J H, L L$ and WG studied and analyzed all of the publications cited in this paper and were involved in the manuscript preparation. WG conducted the final editing and proofreading. All authors read and approved the final manuscript.

\section{Consent for publication}

Not applicable.

\section{Competing interests}

The authors declare that they have no competing interests.

\section{Author details}

'Guangdong Province Key Laboratory of Animal Nutrition Control, College of Animal Science, South China Agricultural University, Guangzhou 510642, China. ${ }^{2}$ College of Animal Science and National Engineering Research Center for Breeding Swine Industry, South China Agricultural University, Guangzhou 510642, China. ${ }^{3}$ Agro-Biological Gene Research Center, Guangdong Academy of Agricultural Sciences, Guangzhou 510640, China.

Received: 26 May 2018 Accepted: 10 September 2018

Published online: 22 October 2018

\section{References}

1. Le Dividich J, Rooke JA, Herpin P. Nutritional and immunological importance of colostrum for the new-born pig. J Agr Sci. 2005;143:469-85.

2. Mei J, Zhang YQ, Wang T, Sangild PT, Xu RJ. Oral ingestion of colostrum alters intestinal transforming growth factor-beta receptor intensity in newborn pigs. Livest Sci. 2006;105:214-22.

3. Quesnel H, Farmer C, Devillers N. Colostrum intake: influence on piglet performance and factors of variation. Livest Sci. 2012;146:105-14.

4. Burrin DG, Shulman RJ, Reeds PJ, Davis TA, Gravitt KR. Porcine colostrum and milk stimulate visceral organ and skeletal muscle protein synthesis in neonatal piglets. J Nutr. 1992;122:1205-13.

5. Tao N, Ochonicky KL, German JB, Donovan SM, Lebrilla CB. Structural determination and daily variations of porcine milk oligosaccharides. J Agric Food Chem. 2010;58:4653-9. 
6. Chen T, Xi QY, Ye RS, Cheng X, Qi QE, Wang SB, et al. Exploration of microRNAs in porcine milk exosomes. BMC Genomics. 2014;15.

7. Martin R, Delgado S, Maldonado A, Jimenez E, Olivares M, Fernandez L, et al. Isolation of lactobacilli from sow milk and evaluation of their probiotic potential. J Dairy Res. 2009;76:418-25.

8. Farmer C, Quesnel H. Nutritional, hormonal, and environmental effects on colostrum in sows. J Anim Sci. 2009;87:56-65.

9. Jensen RG. Handbook of milk composition. San Diego: Academic Press; 1995.

10. Devillers N, Farmer C, Le Dividich J, Prunier A. Variability of colostrum yield and colostrum intake in pigs. Animal. 2007;1:1033-41.

11. German JB, Freeman SL, Lebrilla CB, Mills DA. Human Milk oligosaccharides: evolution, structures and bioselectivity as substrates for intestinal Bacteria. Nestle Nutr Works Se. 2008;62:205-22

12. Musilova S, Rada V, Vlkova E, Bunesova V. Beneficial effects of human milk oligosaccharides on gut microbiota. Benef Microbes. 2014;5:273-83.

13. Salcedo J, Frese SA, Mills DA, Barile D. Characterization of porcine milk oligosaccharides during early lactation and their relation to the fecal microbiome. J Dairy Sci. 2016;99:7733-43.

14. Wu S. Structure elucidation and quantitation of human and primate milk oligosaccharides with mass spectrometry: University of California, Davis, 2012

15. Kunz C, Rudloff S. Health benefits of milk-derived carbohydrates. Bulletin of the International Dairy Federation No. 2002;375(/2002):72-9.

16. Ninonuevo MR, Park Y, Yin HF, Zhang JH, Ward RE, Clowers BH, et al. A strategy for annotating the human milk glycome. J Agric Food Chem. 2006; 54:7471-80.

17. Tao N, Depeters EJ, Freeman S, German JB, Grimm R, Lebrilla CB. Bovine milk glycome. J Dairy Sci. 2008;91:3768-78.

18. Fong B, Ma K, Mcjarrow P. Quantification of bovine Milk oligosaccharides using liquid chromatography-selected reaction monitoring-mass spectrometry. J Agric Food Chem. 2011;59:9788-95.

19. Difilippo E, Pan F, Logtenberg M, Willems RH, Braber S, Fink-Gremmels J, et al. Milk oligosaccharide variation in sow Milk and Milk oligosaccharide fermentation in piglet intestine. J Agric Food Chem. 2016;64:2087-93.

20. Wei J, Wang ZA, Wang B, Jahan M, Wang Z, Wynn PC, et al. Characterization of porcine milk oligosaccharides over lactation between primiparous and multiparous female pigs. Sci Rep. 2018;8:4688.

21. Cummings $\mathrm{H}$, Englyst HN, Wiggins HS. The role of carbohydrates in lower gut function. Nutr Rev. 1986;44:50-4.

22. Peng L, He Z, Chen W, Holzman IR, Lin J. Effects of butyrate on intestinal barrier function in a Caco-2 cell monolayer model of intestinal barrier. Pediatr Res. 2007;61:37-41

23. Wong JM, de Souza R, Kendall CW, Emam A, Jenkins DJ. Colonic health: fermentation and short chain fatty acids. J Clin Gastroenterol. 2006:40:235-43.

24. Hickey RM. The role of oligosaccharides from human milk and other sources in prevention of pathogen adhesion. Int Dairy J. 2012;22:141-6.

25. Manthey CF, Autran CA, Eckmann L, Bode L. Human Milk oligosaccharides protect against Enteropathogenic Escherichia coli attachment in vitro and EPEC colonization in suckling mice. J Pediatr Gastroenterol Nutr. 2014;58:165-8.

26. van Niel G, D'Angelo G, Raposo G. Shedding light on the cell biology of extracellular vesicles. Nat Rev Mol Cell Biol. 2018;19:213-28.

27. Gu Y, Li M, Wang T, Liang Y, Zhong $Z$, Wang $X$, et al. Lactation-related microRNA expression profiles of porcine breast milk exosomes. PLoS One. 2012; 7:e43691.

28. Admyre C, Johansson SM, Qazi KR, Filen JJ, Lahesmaa R, Norman M, et al. Exosomes with immune modulatory features are present in human breast milk. J Immunol. 2007;179:1969-78.

29. Hata T, Murakami K, Nakatani H, Yamamoto Y, Matsuda T, Aoki N. Isolation of bovine milk-derived microvesicles carrying mRNAs and microRNAs. Biochem Biophys Res Commun. 2010;396:528-33.

30. Chen T, Xi QY, Sun JJ, Ye RS, Cheng X, Sun RP, et al. Revelation of mRNAs and proteins in porcine milk exosomes by transcriptomic and proteomic analysis. BMC Vet Res. 2017;13.

31. Rani P, Vashisht M, Golla N, Shandilya S, Onteru SK, Singh D. Milk miRNAs encapsulated in exosomes are stable to human digestion and permeable to intestinal barrier in vitro. J Funct Foods. 2017;34:431-9.

32. Alsaweed M, Hartmann PE, Geddes DT, Kakulas F. MicroRNAs in Breastmilk and the lactating breast: potential Immunoprotectors and developmental regulators for the infant and the mother. Int J Environ Res Public Health. 2015;12:13981-4020.

33. Liao YL, Du XG, Li J, Lonnerdal B. Human milk exosomes and their microRNAs survive digestion in vitro and are taken up by human intestinal cells. Mol Nutr Food Res. 2017;61.

34. Chen T, Xie MY, Sun JJ, Ye RS, Cheng X, Sun RP, et al. Porcine milk-derived exosomes promote proliferation of intestinal epithelial cells. Sci Rep. 2016;6.

35. Martin R, Langa S, Reviriego C, Jimenez E, Marin ML, Xaus J, et al. Human milk is a source of lactic acid bacteria for the infant gut. J Pediatr-Us. 2003; 143:754-8.

36. Espeche MC, Otero MC, Sesma F, Nader-Macias MEF. Screening of surface properties and antagonistic substances production by lactic acid bacteria isolated from the mammary gland of healthy and mastitic cows. Vet Microbiol. 2009;135:346-57.

37. Fernandez L, Langa S, Martin V, Maldonado A, Jimenez E, Martin R, et al. The human milk microbiota: origin and potential roles in health and disease. Pharmacol Res. 2013;69:1-10.

38. Young W, Hine BC, Wallace OA, Callaghan M, Bibiloni R. Transfer of intestinal bacterial components to mammary secretions in the cow. PeerJ. 2015;3:e888.

39. Braem G, De Vliegher S, Verbist B, Heyndrickx M, Leroy F, De Vuyst L. Culture-independent exploration of the teat apex microbiota of dairy cows reveals a wide bacterial species diversity. Vet Microbiol. 2012;157:383-90.

40. Monsallier F, Verdier-Metz I, Agabriel C, Martin B, Montel MC. Variability of microbial teat skin flora in relation to farming practices and individual dairy cow characteristics. Dairy Sci Technol. 2012;92:265-78.

41. Evans PA, Newby TJ, Stokes CR, Bourne FJ. A study of cells in the mammary secretions of sows. Vet Immunol Immunopathol. 1982;3:515-27.

42. Goldman AS. The immune system of human milk: antimicrobial, antiinflammatory and immunomodulating properties. Pediatr Infect Dis J. 1993;12:664-71.

43. Hoebe K, Janssen E, Beutler B. The interface between innate and adaptive immunity. Nat Immunol. 2004;5:971-4.

44. Pomorska-Mol M, Markowska-Daniel I, Bednarek D. Flow Cytometric analysis of leukocytes in porcine mammary secretions. B Vet I Pulawy. 2010:54:188-92.

45. Field CJ. The immunological components of human milk and their effect on immune development in infants. J Nutr. 2005;135:1-4.

46. Rivas RA, el-Mohandes AA, Katona IM. Mononuclear phagocytic cells in human milk: HLA-DR and fc gamma R ligand expression. Biol Neonate. 1994;66:195-204.

47. Schollenberger A, Frymus T, Degorski A, Schollenberger A. Cells of sow mammary secretions. III Some properties of phagocytic cells Zentralbl Veterinarmed A. 1986;33:353-9.

48. Blum JW, Baumrucker CR. Insulin-like growth factors (IGFs), IGF binding proteins, and other endocrine factors in milk: role in the newborn. Adv Exp Med Biol. 2008;606:397-422.

49. Donovan SM, McNeil LK, Jimenez-Flores R, Odle J. Insulin-like growth factors and insulin-like growth factor binding proteins in porcine serum and milk throughout lactation. Pediatr Res. 1994;36:159-68.

50. Westrom BR, Ekman R, Svendsen L, Svendsen J, Karlsson BW. Levels of immunoreactive insulin, neurotensin, and bombesin in porcine colostrum and milk. J Pediatr Gastroenterol Nutr. 1987;6:460-5.

51. Frankshun AL, Ho TY, Steinetz BG, Bartol FF, Bagnell CA. Biological activity of relaxin in porcine milk. Ann N Y Acad Sci. 2009;1160:164-8.

52. Frankshun AL, Ho TY, Reimer DC, Chen J, Lasano S, Steinetz BG, et al. Characterization and biological activity of relaxin in porcine milk. Reproduction. 2011;141:373-80.

53. Jaeger LA, Lamar $\mathrm{CH}$, Bottoms GD, Cline TR. Growth-stimulating substances in porcine milk. Am J Vet Res. 1987;48:1531-3.

54. Manjarin R, Steibel JP, Kirkwood RN, Taylor NP, Trottier NL. Transcript abundance of hormone receptors, mammalian target of rapamycin pathway-related kinases, insulin-like growth factor I, and milk proteins in porcine mammary tissue. J Anim Sci. 2012;90:221-30.

55. Picone G, Zappaterra M, Luise D, Trimigno A, Capozzi F, Motta V, et al. Metabolomics characterization of colostrum in three sow breeds and its influences on piglets' survival and litter growth rates. J Anim Sci Biotechnol. 2018;9:23.

56. Kleiber M, Black AL, Brown MA, Baxter CF, Luick JR, Stadtman FH. Glucose as a precursor of milk constituents in the intact dairy cow. Biochim Biophys Acta. 1955;17:252-60. 
57. Linzell J, Mepham T, Annison E, West C. Mammary metabolism in lactating sows: arteriovenous differences of milk precursors and the mammary metabolism of [14 C] glucose and [14 C] acetate. Br J Nutr. 1969;23:319-33.

58. Zhao FQ, Keating AF. Expression and regulation of glucose transporters in the bovine mammary gland. J Dairy Sci. 2007;90(Suppl 1):E76-86.

59. Zhao FQ, Glimm DR, Kennelly JJ. Distribution of mammalian facilitative glucose transporter messenger RNA in bovine tissues. Int J BioChemiPhysics. 1993;25:1897-903

60. Zhao FQ, Dixon WT, Kennelly JJ. Localization and gene expression of glucose transporters in bovine mammary gland. Comp Biochem Physiol B Biochem Mol Biol. 1996;115:127-34.

61. Macheda ML, Williams ED, Best JD, Wlodek ME, Rogers S. Expression and localisation of GLUT1 and GLUT12 glucose transporters in the pregnant and lactating rat mammary gland. Cell Tissue Res. 2003;311:91-7.

62. Burnol AF, Leturque A, Loizeau M, Postic C, Girard J. Glucose transporter expression in rat mammary gland. Biochem J. 1990;270:277-9.

63. Chen F, Chen B, Guan W, Chen J, Lv Y, Qiao H, et al. Metabolic transition of Milk lactose synthesis and up-regulation by AKT1 in sows from late pregnancy to lactation. Cell Biochem Biophys. 2017;75:131-8.

64. Shu D-P, Chen B-L, Hong J, Liu P-P, Hou D-X, Huang X, et al. Global transcriptional profiling in porcine mammary glands from late pregnancy to peak lactation. Omics. 2012;16:123-37.

65. Neville MC. Introduction: alpha-lactalbumin, a multifunctional protein that specifies lactose synthesis in the Golgi. J Mammary Gland Biol \& Neoplasia. 2009;14:211-2

66. Rudolph MC, Mcmanaman JL, Phang T, Russell T, Kominsky DJ, Serkova NJ, et al. Metabolic regulation in the lactating mammary gland: a lipid synthesizing machine. Physiol Genomics. 2007;28:323-36.

67. Mohammad MA, Hadsell DL, Haymond MW. Gene regulation of UDPgalactose synthesis and transport: potential rate-limiting processes in initiation of milk production in humans. Am J Physiol Endocrinol Metab. 2012:303:E365.

68. Landers E, Burkin H, Bleck G, Howell-Skalla L, Miller D. Porcine B1, 4Galactosyltransferase-I sequence and expression. Reprod Domest Anim. 2009;44:228-34.

69. Zhang Y, Zhang S, Guan W, Chen F, Cheng L, Lv Y, et al. GLUT1 and lactose synthetase are critical genes for lactose synthesis in lactating sows. Nutr Metab (Lond). 2018:15:40.

70. Ramakrishnan B, Shah PS, Qasba PK. Alpha-Lactalbumin (LA) stimulates milk beta-1,4-galactosyltransferase I (beta 4Gal-T1) to transfer glucose from UDPglucose to N-acetylglucosamine. Crystal structure of beta 4Gal-T1 x LA complex with UDP-GIc. J Biol Chem. 2001;276:37665-71.

71. Ramakrishnan B, Qasba PK. Crystal structure of lactose synthase reveals a large conformational change in its catalytic component, the $\beta 1,4$ galactosyltransferase-I. J Mol Biol. 2001;310:205-18.

72. Ramakrishnan B, Balaji PV, Qasba PK. Crystal structure of beta 1,4galactosyltransferase complex with UDP-gal reveals an oligosaccharide acceptor binding site. J Mol Biol. 2002;318:491-502.

73. Ramakrishnan B, Qasba PK. Comparison of the closed conformation of the $\beta 1,4$-galactosyltransferase-1 ( $\beta 4 \mathrm{Gal}-\mathrm{T} 1$ ) in the presence and absence of alactalbumin (LA). J Biomol Struct Dyn. 2003;21(1):-8.

74. Lemay DG, Ballard OA, Hughes MA, Morrow AL, Horseman ND, NommsenRivers LA. RNA sequencing of the human Milk fat layer Transcriptome reveals distinct gene expression profiles at three stages of lactation. PLoS One. 2013;8

75. Huang W, Penagaricano F, Ahmad KR, Lucey JA, Weigel KA, Khatib H. Association between milk protein gene variants and protein composition traits in dairy cattle. J Dairy Sci. 2012;95:440-9.

76. Dettori ML, Pazzola M, Paschino P, Pira MG, Vacca GM. Variability of the caprine whey protein genes and their association with milk yield, composition and renneting properties in the Sarda breed. 1. The LALBA gene. J Dairy Res. 2015;82:434-41.

77. Trottier NL, Shipley CF, Easter RA. Plasma amino acid uptake by the mammary gland of the lactating sow. J Anim Sci. 1997;75:1266-78.

78. Spincer J, Rook JA, Towers KG. The uptake of plasma constituents by the mammary gland of the sow. Biochem J. 1969;111:727-32

79. Laspiur JP, Burton JL, Weber PS, Kirkwood RN, Trottier NL. Short communication: amino acid transporters in porcine mammary gland during lactation. J Dairy Sci. 2004;87:3235-7.

80. Laspiur JP, Burton JL, Weber PS, Moore J, Kirkwood RN, Trottier NL. Dietary protein intake and stage of lactation differentially modulate amino acid transporter mRNA abundance in porcine mammary tissue. J Nutr. 2009;139: 1677-84.

81. Manjarin R, Zamora V, Wu G, Steibel JP, Kirkwood RN, Taylor NP, et al. Effect of amino acids supply in reduced crude protein diets on performance, efficiency of mammary uptake, and transporter gene expression in lactating sows. J Anim Sci. 2012;90:3088-100.

82. Chen F, Zhang S, Deng Z, Zhou Q, Cheng L, Kim SW, et al. Regulation of amino acid transporters in the mammary gland from late pregnancy to peak lactation in the sow. J Anim Sci Biotechnol. 2018;9:35.

83. Palombo V, Loor J, D'Andrea M, Vailati-Riboni M, Shahzad K, Krogh U, et al. Transcriptional profiling of swine mammary gland during the transition from colostrogenesis to lactogenesis using RNA sequencing. BMC Genomics. 2018:19:322.

84. Huber L, de Lange CF, Ernst CW, Krogh U, Trottier NL. Impact of improving dietary amino acid balance for lactating sows on efficiency of dietary amino acid utilization and transcript abundance of genes encoding lysine transporters in mammary tissue. J Anim Sci 2016; 94:4654-4665.

85. Wu G, Knabe DA. Free and protein-bound amino acids in sow's colostrum and milk. J Nutr. 1994:124:415-24.

86. Font-Llitjos M, Rodriguez-Santiago B, Espino M, Sillue R, Manas S, Gomez L, et al. Novel SLC7A7 large rearrangements in lysinuric protein intolerance patients involving the same AluY repeat. Eur J Hum Genet. 2009;17:71-9.

87. Yang JX, Tan QS, Zhu WH, Chen C, Liang XF, Pan L. Cloning and molecular characterization of cationic amino acid transporter $y(+)$ LAT1 in grass carp (Ctenopharyngodon idellus). Fish Physiol Biochem. 2014;40:93-104.

88. Sobey $\mathrm{K}$. The role of the $\mathrm{N}$-terminus in vitamin $\mathrm{C}$ transport and the apical sorting of EGFP-tagged SVCT1 in MDCK cells. Dissertations \& Theses Gradworks. 2009.

89. Bourne $F$, Curtis J. The transfer of immunoglobulins $\lg G$, IgA and $\lg M$ from serum to colostrum and milk in the sow Immunology 1973; 24:157.

90. Schnulle PM, Hurley WL. Sequence and expression of the FCRn in the porcine mammary gland. Vet Immunol Immunopathol. 2003;91:227-31.

91. Theil PK, Hurley W. The protein component of sow colostrum and milk. Edtion ed. Milk Proteins-From Structure to Biological Properties and Health Aspects: InTech, 2016.

92. Su Z, Dong X, Zhang B, Zeng Y, Fu Y, Yu J, et al. Gene expression profiling in porcine mammary gland during lactation and identification of breed-and developmental-stage-specific genes. Science in China Series C. 2006;49:26-36.

93. Hurley W. Composition of sow colostrum and milk. Edtion ed. The gestating and lactating sow. Wageningen: Wageningen Academic Publishers; 2015. p. 115-27.

94. Markowska-Daniel I, Pomorska-Mol M. Shifts in Immunoglobulins levels in the porcine mammary secretions during whole lactation period. B Vet I Pulawy. 2010:54:345-9.

95. Chmurzynska A. The multigene family of fatty acid-binding proteins (FABPs): function, structure and polymorphism. J Appl Genet. 2006:47:39-48.

96. Bionaz M, Loor JJ. ACSL1, AGPAT6, FABP3, LPIN1, and SLC27A6 are the most abundant isoforms in bovine mammary tissue and their expression is affected by stage of lactation. J Nutr. 2008;138:1019-24.

97. Shi HB, Zhu JJ, Luo J, Cao WT, Shi HP, Yao DW, et al. Genes regulating lipid and protein metabolism are highly expressed in mammary gland of lactating dairy goats. Funct Integr Genomics. 2015;15:309-21.

98. Nafikov RA, Schoonmaker JP, Korn KT, Noack K, Garrick DJ, Koehler KJ, et al. Association of polymorphisms in solute carrier family 27 , isoform A6 (SLC27A6) and fatty acid-binding protein-3 and fatty acid-binding protein-4 (FABP3 and FABP4) with fatty acid composition of bovine milk. J Dairy Sci. 2013;96:6007-21.

99. Zhu JJ, Luo J, Wang W, Yu K, Wang HB, Shi HB, et al. Inhibition of FASN reduces the synthesis of medium-chain fatty acids in goat mammary gland. Animal. 2014;8:1469-78.

100. Lv YT, Guan WT, Qiao HZ, Wang CX, Chen F, Zhang YZ, et al. Veterinary medicine and Omics (Veterinomics): metabolic transition of Milk triacylglycerol synthesis in sows from late pregnancy to lactation. Omics. 2015:19:602-16.

101. Toral PG, Frutos P, Hervas G, Gomez-Cortes P, Juarez M, de la Fuente MA. Changes in milk fatty acid profile and animal performance in response to fish oil supplementation, alone or in combination with sunflower oil, in dairy ewes. J Dairy Sci. 2010;93:1604-15.

102. Hristov AN, Lee C, Cassidy T, Long M, Heyler K, Corl B, et al. Effects of lauric and myristic acids on ruminal fermentation, production, and milk fatty acid composition in lactating dairy cows. J Dairy Sci. 2011;94:382-95. 
103. Klobasa F, Werhahn E, Butler JE. Composition of sow milk during lactation. J Anim Sci. 1987;64:1458-66.

104. Kim JS, Hosseindoust A, Ju IK, Yang X, Lee SH, Noh HS, et al. Effects of dietary energy levels and $\beta$-mannanase supplementation in a high mannan-based diet during lactation on reproductive performance, apparent total tract digestibility and milk composition in multiparous sows. Ital J Anim Sci. 2017:1-7.

105. Tian ML, Wang N, Su G, Shi BM, Shan AS. Effects of dietary L-Carnitine and fat type on the performance, Milk composition and immunoglobulin in sows, and immunological variables of sows and piglets during late gestation and lactation. Czech J Anim Sci. 2017;62:185-94.

106. Bai YS, Wang CQ, Zhao X, Shi BM, Shan AS. Effects of fat sources in sow on the fatty acid profiles and fat globule size of milk and immunoglobulins of sows and piglets. Anim Feed Sci Tech. 2017;234:217-27.

107. Wang J, Yang M, Cao M, Lin Y, Che LQ, Duraipandiyan V, et al. Moderately increased energy intake during gestation improves body condition of primiparous sows, piglet growth performance, and milk fat and protein output. Livest Sci. 2016;194:23-30.

108. Shen Y, Wan HF, Zhu JT, Fang ZF, Che LQ, Xu SY, et al. Fish oil and olive oil supplementation in late pregnancy and lactation differentially affect oxidative stress and inflammation in sows and piglets. Lipids. 2015;50:647-58.

109. Decaluwe R, Maes D, Cools A, Wuyts B, De Smet S, Marescau B, et al. Effect of peripartal feeding strategy on colostrum yield and composition in sows. J Anim Sci. 2014;92:3557-67.

110. Wang LS, Su BC, Shi Z, Shi BM, Shan AS. Dietary supplementation with maize distillers dried grains with solubles during late gestation and lactation: effects on sow and litter performance, and on colostrum and milk composition. Anim Feed Sci Tech. 2013;179:149-53.

111. Samanc H, Sladojevic Z, Vujanac I, Prodanovic R, Kirovski M, Dodovski P, et al. Relationship between growth of nursing pigs and composition of sow colostrum and Milk from anterior and posterior mammary glands. Acta VetBeograd. 2013;63:537-48.

112. Loisel F, Farmer C, Ramaekers P, Quesnel H. Effects of high fiber intake during late pregnancy on sow physiology, colostrum production, and piglet performance. J Anim Sci. 2013;91:5269-79.

113. Krogh U, Flummer C, Jensen SK, Theil PK. Colostrum and milk production of sows is affected by dietary conjugated linoleic acid. J Anim Sci. 2012;90: 366-8.

114. Flummer C, Theil PK. Effect of beta-hydroxy beta-methyl butyrate supplementation of sows in late gestation and lactation on sow production of colostrum and milk and piglet performance. J Anim Sci. 2012;90(Suppl 4):372-4.

115. Zhao PY, Zhang ZF, Lan RX, Liu WC, Kim IH. Effect of lysophospholipids in diets differing in fat contents on growth performance, nutrient digestibility, milk composition and litter performance of lactating sows. Animal. 2017;11: 984-90.

116. Velayudhan DE, Nyachoti CM. Effect of increasing dietary canola meal inclusion on lactation performance, milk composition, and nutrient digestibility of lactating sows. J Anim Sci. 2017;95:3129-35.

117. Rosero DS, Odle J, Mendoza SM, Boyd RD, Fellner V, van Heugten E. Impact of dietary lipids on sow milk composition and balance of essential fatty acids during lactation in prolific sows. J Anim Sci. 2015;93:2935-47.

118. Farmer C, Palin MF, Theil PK, Sorensen MT, Devillers N. Milk production in sows from a teat in second parity is influenced by whether it was suckled in first parity. J Anim Sci. 2012;90:3743-51.

119. Park MS, Shinde PL, Yang YX, Kim JS, Choi JY, Yun K, et al. Reproductive performance, Milk composition, blood metabolites and hormone profiles of lactating sows fed diets with different cereal and fat sources. Asian Australas J Anim Sci. 2010;23:226-33.

120. Wang CQ, Bai YS, Zhao X, Shi BM, Meng XY, Shan AS. Effects of feeding sodium stearoyl-2-lactylate diets to lactating sows on performance, digestibility of nutrients, composition, and fat globule size in milk. J Anim Sci. 2017:95:5091-9.

121. Mudd AT, Salcedo J, Alexander LS, Johnson SK, Getty CM, Chichlowski M, et al. Porcine Milk oligosaccharides and Sialic acid concentrations vary throughout lactation. Frontiers in nutrition. 2016;3:39.

122. Amusquivar E, Laws J, Clarke L, Herrera E. Fatty acid composition of the maternal diet during the first or the second half of gestation influences the fatty acid composition of sows' Milk and plasma, and plasma of their piglets. Lipids. 2010;45:409.

123. Bee G. Dietary conjugated linoleic acids alter adipose tissue and milk lipids of pregnant and lactating sows. J Nutr. 2000;130:2292-8.

\section{Ready to submit your research? Choose BMC and benefit from:}

- fast, convenient online submission

- thorough peer review by experienced researchers in your field

- rapid publication on acceptance

- support for research data, including large and complex data types

- gold Open Access which fosters wider collaboration and increased citations

- maximum visibility for your research: over $100 \mathrm{M}$ website views per year

At BMC, research is always in progress.

Learn more biomedcentral.com/submissions 